\title{
Pain, health-related quality of life and health care utilization after inpatient surgery: A pilot study
}

\author{
Elizabeth G VanDenKerkhof RN PhD, Wilma M Hopman MA, Tanveer Towheed MSc FRCPC, \\ Rosemary Wilson RN MN, John Murdoch FRCA, Michael Rimmer, Sherri Schmidt Stutzman BScN, \\ Debbie Tod RN, Vico Dagnone MSc, David H Goldstein MSc FRCPC
}

EG VanDenKerkhof, WM Hopman, T Towheed, et al. Pain, health-related quality of life and health care utilization after inpatient surgery: A pilot study. Pain Res Manage 2006;11(1):41-47.

BACKGROUND: Little is known about pain-related outcomes in surgical inpatients after discharge from the hospital. An ongoing risk and outcomes monitoring system would provide valuable feedback to improve the quality of patient care.

OBJECTIVES: The purpose of the present pilot study was to describe postoperative pain, medication use, health care utilization and health-related quality of life (HRQOL) immediately and four weeks after surgery; merge clinically captured data with Web-based follow-up data; and examine patients' willingness to complete Webbased health questionnaires.

METHODS: One hundred two consecutive surgical inpatients were approached for participation. Perioperative data were abstracted from the acute pain management service clinical database and linked to follow-up data captured four weeks postoperatively.

RESULTS: Follow-up questionnaires were completed by 88 participants. Clinical assessment data were successfully linked to Web-based follow-up data. Average pain intensity (3.7) four weeks following discharge fell just short of the acute pain management service active pain score of 3.9. At four weeks, all 88 participants reported significantly impaired HRQOL, 36 were still taking pain medications and 15 had visited an emergency room. Two-thirds of the participants had access to the Internet at home and approximately one-half were willing to complete on-line health questionnaires.

DISCUSSION: The study indicates that it is feasible to link clinical and research data, and shows a significant burden of pain and reduced HRQOL in the weeks following discharge. This approach to converting clinically captured data into meaningful information about surgical outcomes is valuable in the development of an ongoing risk and outcomes monitoring system.

Key Words: Canada; Computerized health data; Health care utilization; Health-related quality of life; Postoperative pain; Prospective study

\section{Douleur, qualité de vie liée à la santé et utilisation des soins de santé après une intervention chirurgicale chez des malades hospitalisés : étude pilote}

\begin{abstract}
CONTEXTE : On connaît peu de choses sur l'état de la douleur chez les malades hospitalisés ayant subi une intervention chirurgicale, après leur congé. Un système de surveillance continue des risques et des résultats permettrait de recueillir des données utiles pour améliorer la qualité des soins aux patients.
\end{abstract}

BUTS : La présente étude pilote avait pour buts d'obtenir une description de la douleur postopératoire, de l'utilisation des médicaments et des soins de santé ainsi que de la qualité de vie liée à la santé (QVLS) immédiatement après l'intervention et quatre semaines plus tard; de fusionner des données recueillies en clinique et des données de suivi recueillies dans un site Web; d'évaluer la volonté des patients de remplir les questionnaires sur la santé, présentés dans un site Web.

MÉTHODE : Nous avons demandé à 102 patients consécutifs, hospitalisés pour une opération de participer à l'étude. Les données recueillies pendant la phase périopératoire ont été tirées de la base de données cliniques du service de traitement de la douleur aiguë, puis mises en lien avec les données de suivi recueillies quatre semaines après l'intervention.

RÉSULTATS : Quatre-vingt-huit patients ont rempli les questionnaires de suivi. Nous avons réussi à établir un lien entre les données sur l'évaluation clinique et les données de suivi versées dans le site Web. L'intensité moyenne de la douleur $(3,7)$ quatre semaines après le congé se tenait tout juste au-dessous du score de la douleur assez forte $(3,9)$, établi par le service de traitement de la douleur aiguë. Au bout de quatre semaines, tous les répondants (88) ont fait état d'une QVLS passablement perturbée, 36 prenaient encore des analgésiques et 15 s'étaient rendus au service d'urgence. Les deux tiers des participaient avaient un accès Internet à domicile et environ la moitié était disposée à remplir les questionnaires en ligne sur la santé.

DISCUSSION : L'étude montre qu'il est possible d'établir un lien entre des données cliniques et des données de recherche; de plus, elle révèle l'existence d'une douleur importante et une diminution de la QVLS au cours des semaines suivant l'opération. La transformation des données recueillies en clinique en information significative sur les résultats de la chirurgie s'avère très utile dans l'élaboration d'un système de surveillance continue des risques et des résultats. 
A lmost all surgical patients experience pain postoperatively. Little is known about pain-related outcomes after discharge from the hospital. The physiological changes that can occur from poorly controlled acute postsurgical pain include cardiovascular and respiratory changes, immobility, depression of the immune system, disturbed sleep, poor appetite and nutrition, and dependence on medication (1).

While no single cause of chronic postsurgical pain has been identified, recent evidence (2,3) suggests that the effective treatment of acute pain after surgery can reduce hospital length of stay, enhance functional recovery and improve longterm functional outcomes. The management of postoperative pain is important not only because of its impact on health care resources (4) and health-related quality of life (HRQOL) (5) in the immediate postoperative period, but also because it may result in chronic pain $(3,6)$ and has a profound negative impact on all aspects of HRQOL $(7,8)$. Studies examining postoperative pain management in ambulatory patients found that there was still significant pain at $24 \mathrm{~h}$ (9) through seven days $(10,11)$. However, $50 \%$ of participants had stopped analgesic use after $72 \mathrm{~h}$, possibly related to side effects (10), suggesting that pain management may not be optimal in many patients following discharge from the hospital. Surgical inpatients usually experience more invasive surgery and have more comorbidities than ambulatory surgery patients; however, there appear to be no studies that examined the level of postoperative pain and HRQOL in surgical inpatients after discharge from hospital.

The rationale for the development of the present program of research was that adequate knowledge of surgical outcomes will be gained only through the development of an ongoing prospective monitoring system that captures patient information both perioperatively and after hospital discharge. The purpose of the present feasibility study was threefold: to describe the experience of surgical inpatients with respect to postoperative pain, medication use, health care utilization and HRQOL four weeks postoperatively; to assess the utility of merging clinically captured perioperative data with a Webbased telephone follow-up system; and to examine patients' willingness to report follow-up data by telephone or the Internet.

\section{METHODS}

Between March 22 and April 25, 2004, 102 consecutive surgical patients who were followed by treatment at the acute pain management service (APMS) were approached for participation. Inpatient data were abstracted from the APMS electronic system, which incorporates demographic and surgical data from the hospital information system, with assessment information captured electronically on a tablet at the bedside by the APMS (12). Assessment data included pain-related medications, pain scores (rest and active on a verbal numeric rating scale of 0 to 10 , with 0 representing no pain) and side effects of therapy. Four weeks postoperatively, participants were contacted by telephone and asked questions about pain, prescriptions and health care utilization in the previous four weeks. The Medical Outcomes Trust 36-item short form health survey (SF-36) $(13,14)$ and a questionnaire about computer and Internet use were also completed at this time. The SF-36 is a 36-item questionnaire used to measure the patients' own perception of their HRQOL, pain and function. It is generic, rather than disease-specific, making it applicable across a wide variety of patient populations. It yields eight domain scores: physical functioning; role physical; role emotional; bodily pain; general health perceptions; vitality; social function; and mental health. Higher scores represent better function (13). In addition, a physical component summary and a mental component summary can be derived (14). The physical component summary and mental component summary use norm-based scoring, so that the population mean is standardized to 50 and one SD is equal to 10 points (14). Ethics approval for the study was obtained from the Queen's University Research Ethics Board.

Data were entered into a Web-based structured query language (SQL) server database by the research nurse during telephone follow-up. The follow-up database was linked to the APMS SQL database with a unique identifier that was assigned to each participant at study enrollment. The combined data from the SQL server database were converted to a spreadsheet and imported into SPSS version 12.0 (SPSS Inc, USA) for statistical analysis. Age- and sex-adjusted normative data for the SF-36 (15) were included for each patient. Following descriptive statistics, the associations between the five pain scores (average rest and active, maximum rest and active pain scores postoperatively, and average pain score during the four week follow-up) were assessed by means of correlation. The associations between pain scores, health care utilization, age, surgical category and sex were assessed by using correlations, independent sample $t$ tests, one-way ANOVA and $\chi^{2}$ tests. SF-36 scores were compared with the age- and sex-adjusted normative data by using paired sample $t$ tests. Consideration must be given to the fact that the feasibility study was not powered to detect specific effect sizes, but rather to identify statistically significant associations between factors thought to be clinically related to pain outcomes. Lack of statistical significance between apparently clinically significant results may be due to small sample size, while multiple testing may result in statistical significance by chance alone. The purpose of the analysis was to provide information for a larger study rather than definitive information about factors affecting the pain outcomes and HRQOL. A P value less than 0.05 was considered statistically significant.

\section{RESULTS}

Three of 102 patients approached for participation refused. At the four-week follow-up contact, three participants could not be reached, seven refused participation and one withdrew partway through the follow-up questionnaire. The response rate for recruitment into the study was $97 \%$ (99 of 102) and 89\% (88 of 99) of participants completed the study. Table 1 contains the age, postoperative length of stay, sex, surgical category and side effects for both the in-hospital $(n=99)$ and the follow-up samples $(n=88)$. Within the surgical categories for the follow-up sample, the mean age \pm SD ranged from $51.2 \pm 18.6$ years (general surgery) to $62.0 \pm 4.7$ years (urology) but the between-group differences did not attain statistical significance $(P=0.103)$. The median length of stay after surgery was 6.0 days and varied by surgical category, ranging from four days for gynecological surgery to 7.5 days for cardiac/thoracic surgery. The most commonly reported side effect was nausea $(40 \%)$.

Table 2 contains the mean and SD for the APMS maximum pain score (rest and active), the average pain score (rest and active) and the follow-up pain score. Although three of the pain measures were normally distributed, two (APMS average and maximum pain scores at rest) were not; therefore, the median and interquartile ranges are also provided. Participants reported their average pain intensity in the four weeks following discharge as 3.7 of 10 , which exceeded both 
TABLE 1

Inpatient and follow-up sample patient characteristics

\begin{tabular}{lcc}
\hline & $\begin{array}{c}\text { Inpatient } \\
\text { sample (n=99) }\end{array}$ & $\begin{array}{c}\text { Follow-up } \\
\text { sample (n=88) }\end{array}$ \\
\hline $\begin{array}{l}\text { Numeric variables, mean (SD) } \\
\text { Age (range 17 years to 86 years) }\end{array}$ & $57(16)$ & $57(16)$ \\
Length of stay postoperatively & $7.5(6.3)$ & $6.9(4.4)$ \\
(Range one day to 24 days) & (median=6.0) & (median=6.0) \\
Categorical variables, $\mathrm{n}$ (\%) & & \\
Men & $42(42)$ & $39(44.3)$ \\
Surgical category, n (\%) & & \\
Obstetrics/gynecology & $13(13)$ & $12(14)$ \\
General & $32(32)$ & $30(34)$ \\
Orthopedics & $36(36)$ & $30(34)$ \\
Thoracic/vascular & $12(12)$ & $10(11)$ \\
Urology & $6(6.1)$ & $6(6.8)$ \\
Inpatient side effects/problems, $\mathrm{n}(\%)$ & \\
Nausea & $39(39)$ & $35(40)$ \\
Vomiting (one missing) & $16(16)$ & $14(16)$ \\
Pruritus (three missing) & $8(8.4)$ & $8(9.1)$ \\
Sedation (five missing) & $10(11)$ & $7(8.0)$ \\
Insomnia (14 missing) & $23(27)$ & $19(22)$ \\
Hypotension (13 missing) & $6(7.0)$ & $5(5.7)$ \\
\hline
\end{tabular}

TABLE 2

Pain ratings on the acute pain management service (APMS) and at follow-up ( $n=88)$

\begin{tabular}{lcc}
\hline Characteristic (numeric variables) & Mean (SD) & $\begin{array}{l}\text { Median (inter- } \\
\text { quartile range) }\end{array}$ \\
\hline Maximum APMS rest pain score (0-10) & $2.2(2.4)$ & $2.0(0-4.0)$ \\
Maximum APMS active pain score (0-10) & $4.6(2.7)$ & $5.0(4.0-7.8)$ \\
Average APMS rest pain score (0-10) & $1.6(1.7)$ & $1.2(0-2.3)$ \\
Average APMS active pain score (0-10) & $3.9(2.1)$ & $4.0(2.3-5.0)$ \\
Average pain intensity on follow-up (0-10) & $3.7(2.2)$ & $3.0(2.0-5.0)$ \\
\hline
\end{tabular}

of the APMS inpatient resting pain scores (maximum and average) and fell just short of the average APMS average active pain score of 3.9 .

Rest pain scores did not follow a Gaussian distribution; therefore, both Pearson and Spearman rank order correlations were generated. However, the results of the two correlation methods were similar. The Pearson correlations are reported here. All four in-hospital APMS pain scores (average rest and active, and maximum rest and active pain scores postoperatively), and the follow-up pain score were highly correlated, ranging from a high of $0.860(\mathrm{P}<0.001)$ for the APMS maximum and average rest pain scores to a low of $0.255(\mathrm{P}=0.017)$ for the APMS maximum rest score and the follow-up score. Four of five pain scores also correlated highly with the bodily pain domain of the SF-36 ( $<<0.01$ for all), while the fifth fell just short of statistical significance (APMS maximum pain score, $\mathrm{P}=0.051$ ).

There were no significant differences among the surgical categories for the mean APMS maximum rest pain score (range 1.1 \pm 1.6 for the obstetrics/gynecology group to 3.2 \pm 2.0 for the orthopedics group, $\mathrm{P}=0.16)$ or for the mean APMS

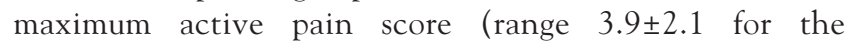
obstetrics/gynecology group to $5.9 \pm 2.0$ for the orthopedics group, $\mathrm{P}=0.13)$. There were significant between-group differences for the APMS average rest pain score, but post hoc testing (Tukey's) revealed that the only significant difference was
TABLE 3

Follow-up medication and usage information $(n=88)$

\begin{tabular}{lc}
\hline Variable & $\mathbf{n}(\%)$ \\
\hline Pain since discharge & $80(90.9)$ \\
Location (\% based on subset of 80 with pain) & \\
$\quad$ Surgical site & $48(60.0)$ \\
Other location & $9(11.3)$ \\
Both & $23(28.8)$ \\
Prescription for pain at discharge? & $71(80.7)$ \\
$\quad$ Prescription filled? (\% based on subset with prescription) & $65(91.5)$ \\
Taking other pain medication? & $36(40.9)$ \\
Medication side effects?* & $27(30.7)$ \\
Usage & \\
Visited doctor or clinic & $58(65.9)$ \\
Emergency room visit & $15(17.0)$ \\
Telephoned for advice & $14(15.9)$ \\
Readmitted to hospital & $10(11.4)$ \\
Pain information given at discharge & $44(50.0)$ \\
It was adequate (\% based on subset given information) & $41(93.2)$ \\
\hline
\end{tabular}

${ }^{*}$ Constipation (15 patients), nausea (three patients) and a variety of individual observations, such as fatigue, dizziness and heartburn (nine patients)

between the lowest $(0.8 \pm 1.3$ for obstetrics/gynecology) and highest $(2.3 \pm 2.1$ for orthopedics) pain groups $(\mathrm{P}=0.048)$. APMS average active pain score also differed among groups. Mean scores ranged from $2.6 \pm 1.7$ for the obstetrics/gynecology group to $5.0 \pm 1.9$ for the orthopedics group, with significant differences between the orthopedics group versus the obstetrics/gynecology group $(\mathrm{P}=0.004)$, the general surgery group (mean 3.6 $\pm 2.1, \mathrm{P}=0.041$ ) and the thoracic/vascular group (mean $3.0 \pm 2.0, \mathrm{P}=0.041$ ) on post hoc testing. Pain intensity four weeks after discharge ranged from $2.0 \pm 1.7$ for urology to $4.1 \pm 1.9$ for orthopedics, but the difference among surgical categories did not attain statistical significance $(\mathrm{P}=0.20)$.

Table 3 presents information regarding follow-up medication and use. Eighty (91\%) patients indicated that they had experienced pain since discharge. Of 71 who had received a prescription, only six did not fill it. Over one-half of the patients indicated that they had been to the doctor or a clinic in the past four weeks, but many of these visits were scheduled visits for postoperative assessment or removal of stitches or staples. At four weeks, 36 (41\%) participants were still taking pain medication: 29 patients were taking acetaminophen; one was taking ibuprofen; and six were taking prescription medication. Constipation was the most frequently cited side effect, reported by just over one-half $(n=15)$ of those who reported side effects from their medication $(n=27)$.

One-half of patients reported receiving information about pain management at the time of discharge; three of these patients felt that the information was inadequate. This question was designed in such a way that only those who had received information were to respond, but an additional nine who did not receive information answered this question negatively. There were no significant differences in health care utilization between the 80 patients who reported pain following discharge and the eight patients who did not.

There was no statistically significant difference in the mean age of men ( $56 \pm 15$ years) and women ( $58 \pm 16$ years). Women were more likely to experience nausea (51\% compared with $26 \%$ of men, $\mathrm{P}=0.018)$ and vomiting (25\% compared with 
TABLE 4

Mean age and follow-up pain scores for prescription and usage information $(n=88)$

\begin{tabular}{|c|c|c|c|c|c|c|}
\hline \multirow[b]{2}{*}{ Variable } & \multicolumn{3}{|c|}{ Mean age, years } & \multicolumn{3}{|c|}{$\begin{array}{l}\text { Mean follow-up } \\
\text { pain score }\end{array}$} \\
\hline & No & Yes & $\mathbf{P}$ & No & Yes & $\mathbf{P}$ \\
\hline $\begin{array}{l}\text { Received prescription } \\
\text { for pain }\end{array}$ & 67.2 & 54.6 & 0.002 & 2.2 & 4.0 & 0.002 \\
\hline $\begin{array}{l}\text { Filled prescription } \\
\text { (subset of 71) }\end{array}$ & 59.9 & 54.8 & 0.40 & 1.9 & 4.2 & 0.008 \\
\hline $\begin{array}{l}\text { Taking other pain } \\
\text { medications }\end{array}$ & 56.8 & 56.7 & 0.97 & 3.8 & 3.6 & 0.61 \\
\hline Medication side effects & 55.9 & 57.5 & 0.68 & 3.6 & 4.4 & 0.12 \\
\hline $\begin{array}{l}\text { Doctor or clinic visit in } \\
\text { the past four weeks }\end{array}$ & 57.3 & 56.9 & 0.92 & 3.5 & 3.8 & 0.51 \\
\hline $\begin{array}{l}\text { Emergency room visit in } \\
\text { the past four weeks }\end{array}$ & 57.6 & 54.5 & 0.49 & 3.5 & 4.6 & 0.035 \\
\hline $\begin{array}{l}\text { Phone advice in the } \\
\text { past four weeks }\end{array}$ & 57.2 & 54.5 & 0.56 & 3.5 & 4.8 & 0.038 \\
\hline Readmitted & 57.1 & 56.7 & 0.94 & 3.7 & 3.9 & 0.74 \\
\hline $\begin{array}{l}\text { Pain information given } \\
\text { at discharge }\end{array}$ & 62.8 & 51.3 & $<0.001$ & 3.6 & 3.7 & 0.85 \\
\hline $\begin{array}{l}\text { Information adequate } \\
\text { (subset of } 44 \text { ) }\end{array}$ & 65.7 & 50.2 & 0.07 & 2.0 & 3.9 & 0.13 \\
\hline
\end{tabular}

\section{TABLE 5}

Frequency and age of participants responding to the computer-related questionnaire

\begin{tabular}{|c|c|c|c|c|c|}
\hline \multirow[b]{2}{*}{ Variable* $^{*}$} & \multirow[b]{2}{*}{ n (\%) } & \multicolumn{2}{|c|}{ Mean age (SD) } & \multirow[b]{2}{*}{$\chi^{2}$} & \multirow[b]{2}{*}{$\mathbf{P}$} \\
\hline & & Yes & No & & \\
\hline Have home computer & $68(77)$ & $53(16)$ & $66(11)$ & 10.6 & $<0.01$ \\
\hline Use computer & $52(59)$ & $50(15)$ & $66(13)$ & 27.6 & $<0.01$ \\
\hline Have Internet at home & $58(66)$ & $54(16)$ & $61(16)$ & 4.84 & 0.03 \\
\hline Use Internet $(n=86)$ & $44(51)$ & $51(14)$ & $63(15)$ & 15.6 & $<0.01$ \\
\hline \multicolumn{6}{|l|}{ Willing to access pain } \\
\hline information on-line & $45(51)$ & $50(15)$ & $62(15)$ & 14.4 & $<0.01$ \\
\hline \multicolumn{6}{|l|}{ Willing to complete } \\
\hline on-line questionnaire & $43(49)$ & $51(14)$ & $61(16)$ & 9.66 & $<0.01$ \\
\hline \multicolumn{6}{|c|}{ Willing to complete on-line } \\
\hline health questionnaire & $42(48)$ & $50(14.7)$ & $62(15)$ & 13.4 & $<0.01$ \\
\hline
\end{tabular}

$5.1 \%$ of men, $\mathrm{P}=0.017)$. There were no sex differences in any of the pain outcomes. Medication use, health care utilization and SF-36 domain scores also did not differ by sex, although the physical functioning domain of the SF-36 approached significance ( 48 for men and 38 for women, $\mathrm{P}=0.055$ ).

Table 4 contains the mean age and follow-up pain scores by medication and health care usage. Those who received a prescription were significantly younger ( 55 years versus 67 years, $\mathrm{P}=0.002$ ) than those who did not, as were those who received information about pain management ( 51 years versus 63 years, $\mathrm{P}<0.001)$. There were no differences in utilization by age. All of the correlations between age and the five pain scores were negative, suggesting that older participants reported less pain. However, only one correlation (age and APMS average rest pain score) approached significance $(\mathrm{r}=-0.186, \mathrm{P}=0.082)$.

Patients who received a prescription for analgesia at discharge reported higher pain scores at follow-up than did those who did not receive a prescription (Table 4). Of the subset receiving a prescription, those who had it filled also reported

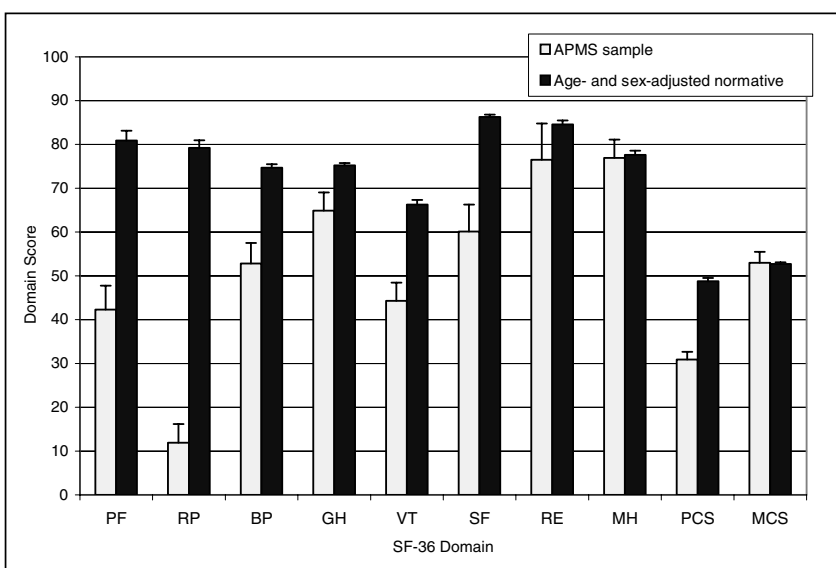

Figure 1) Mean follow-up scores for the 36-item health survey (SF-36) for the acute pain management service (APMS) patients compared with normative data $(n=88)$. Error bars represent the 95\% CI of the mean values. BP Bodily pain; GH General health; MCS Mental component summary; MH Mental health; PCS Physical component summary; PF Physical function; RE Role emotional; RP Role physical; SF Social function; VT Vitality

significantly higher pain scores than those who did not have it filled. Not surprisingly, those who had visited an emergency room in the past four weeks and those who had telephoned for advice regarding pain medications had significantly higher pain scores than those who did not $(\mathrm{P}<0.05$ for both).

As expected, all 88 participants reported significantly impaired HRQOL in the four weeks following discharge from the APMS as compared with age and sex adjusted normative data. The extent of the impairment for the eight domains and the two summary components of the SF-36 is quantified in Figure 1. There are statistically significant differences $(\mathrm{P}<0.001$ in all cases $)$ for the domains physical functioning, role physical, bodily pain, general health, vitality and social function, as well as the physical component summary. The difference for role emotional approached significance $(\mathrm{P}=0.061)$. The patient scores were not significantly different from the normative data for the mental health domain $(\mathrm{P}=0.73)$ and component summary $(\mathrm{P}=0.88)$.

Table 5 contains responses to questions related to computer and Internet use. Two-thirds of the participants had access to the Internet at home and almost one-half were willing to complete on-line health questionnaires.

\section{DISCUSSION}

Postoperative pain and outcomes at the four-week follow-up The data from this feasibility study provide a unique insight into pain, medication use, health care utilization and HRQOL in surgical inpatients following discharge from hospital. Consistent with the literature (9-11) on pain after ambulatory surgery, patients in the present study - where in some cases the expectation of pain may be zero - experienced moderate to severe pain in the weeks following discharge (range two to five of 10). While the literature (10) supports minimal use of analgesics after discharge by surgical patients, there also appeared to be a reluctance to provide older participants with information about and prescriptions for pain management, even though there was no statistically significant difference in pain intensity by age. Given that there was no difference in 
age distribution across surgical categories, this difference was unlikely to be due to type of surgery. The reluctance to provide prescriptions may be due to concurrent medications or comorbid conditions in older participants, although this was not tested in the study. Emergency room visits and advice-seeking were higher in participants reporting pain, suggesting that poorly managed pain following discharge may have a significant impact on health care utilization. Given the correlation between APMS pain scores and follow-up pain scores, further study is required to determine whether reduction of pain in hospital results in reduced follow-up pain and health care utilization. The lower levels of HRQOL found in the present study were expected; however, this is the first time the burden of illness and disability has been quantified from the participants' point of view.

\section{Feasibility of combining clinical and Web-based telephone follow-up data}

The majority of participants completed the telephone interview at follow-up (89\%); however, considerable time was spent attempting to contact participants at follow-up. On the basis of participant responses, approximately one-half of the participants would have responded to an on-line health questionnaire, and younger participants were more likely to have computer access and Internet access and respond to Internet questionnaires, suggesting that a combination of Internet and telephone follow-up will be necessary to capture surgical outcomes data in this manner.

The descriptive data presented here serve as an overview of the present sample of patients and must be interpreted with caution due to the large number of statistical tests conducted, increasing the likelihood of achieving statistical significance by chance alone. The provision of actual $\mathrm{P}$ values allows for an assessment of the degree of significance. In addition, the study was not powered to assess each of the analyses; therefore, a statistically significant result may not be considered clinically significant. However, all descriptive data are presented, allowing for the application of clinical judgement when interpreting the results. With respect to generalizability, 97\% of the patients approached agreed to participate in the study, and of these $89 \%$ were successfully contacted four weeks postoperatively. Due to one of the primary objectives of converting clinically acquired data to outcomes information, patients were limited to those admitted to the APMS, where electronic capture of assessment data is part of routine care. As such, these participants may be undergoing surgery that induces high levels of pain, resulting in the need for the APMS follow-up. Inclusion of all surgical inpatients may result in lower levels of reported pain overall.

Advantages of the present study include its prospective nature. Patients were admitted to the APMS and were followed up throughout their hospital stay and four weeks postoperatively. Data captured during clinical assessments were linked with follow-up data and analyzed to provide information about the association between postoperative characteristics and outcomes four weeks postoperatively. This approach to converting clinically captured data into meaningful information about surgical outcomes is an important step in the development of an ongoing risk and outcomes monitoring system in acute care. The study provides information not only about the feasibility of linking clinical and research data, but also about the feasibility of capturing follow-up data by telephone interviews and the potential for on-line data capture of outcomes-monitoring data.

In conclusion, the pilot data captured in the present study not only indicate that it is feasible to link clinical and research data, but also show a significant burden of pain and reduced HRQOL in the weeks following discharge. This supports the need for outcomes monitoring beyond discharge, because poorly managed pain following discharge may have a significant impact on health care utilization.

FUNDING: A Queen's University Research Initiation Grant funded Web-based tool development. The wireless infrastructure and software development were supported by funding from the Canadian Foundation for Innovation, Ontario Innovative Trust, Queens University, Kingston General Hospital, and Health Evidence Application and Linkage Network.

\begin{tabular}{|c|c|c|c|}
\hline \multicolumn{4}{|c|}{$\begin{array}{c}\text { APPENDIX } 1 \\
\text { Data collection form }\end{array}$} \\
\hline \multicolumn{4}{|c|}{ Data Collection Form } \\
\hline \multicolumn{4}{|c|}{ Four-Week Follow-Up of Patients Discharged from the Acute Pain Service } \\
\hline 1. Have you had pain since your hospital discharge? & $\square$ No & $\square$ Yes & \\
\hline If yes, is this pain: & $\begin{array}{l}\square \text { wher } \\
\square \text { pain } \\
\square \text { both }\end{array}$ & $\begin{array}{l}\text { ou had the surgery } \\
\text { other location(s) }\end{array}$ & \\
\hline $\begin{array}{l}\text { How would you rate the pain (on average), with } \\
0 \text { being no pain and } 10 \text { being pain as bad as } \\
\text { it could be? }\end{array}$ & $\begin{array}{lll}0 & 1 & 2\end{array}$ & $\begin{array}{llllll}4 & 5 & 6 & 7 & 8 & 9\end{array}$ & \\
\hline 2. Did you receive a prescription for pain medication? & $\square$ No & $\square$ Yes & \\
\hline If yes, did you get the prescription filled? & $\square$ No & $\square$ Yes & \\
\hline If you did not fill the prescription, why not? & & & \\
\hline $\begin{array}{l}\text { 3. Are you taking any other medication for pain? } \\
\text { (e.g. Tylenol, Aspirin or Advil) }\end{array}$ & $\square$ No & $\square$ Yes & \\
\hline If yes, which one(s)? & & & \\
\hline What dose and how often? & & & \\
\hline $\begin{array}{l}\text { 4. Have you had any side effects from the medications } \\
\text { (e.g. heartburn, constipation, nausea?) }\end{array}$ & $\square$ No & $\square$ Yes & $\square \mathrm{n} / \mathrm{a}$ \\
\hline If yes, which side effects? & & & \\
\hline Which medication is causing this? & & & \\
\hline $\begin{array}{l}\text { 5. Have you seen your family doctor or visited a walk-in } \\
\text { clinic in the past } 4 \text { weeks? }\end{array}$ & $\square$ No & $\square$ Yes & \\
\hline If yes, how often? & 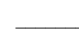 & & \\
\hline $\begin{array}{l}\text { 6. Have you been to the Emergency Department in the } \\
\text { past } 4 \text { weeks? }\end{array}$ & $\square$ No & $\square$ Yes & \\
\hline If yes, how often? & & & \\
\hline $\begin{array}{l}\text { 7. Have you phoned anyone (doctor, nurse, pharmacist) } \\
\text { to ask about pain medication in the past } 4 \text { weeks? }\end{array}$ & $\square$ No & $\square$ Yes & \\
\hline If yes, who? & & & \\
\hline And how often? & & & \\
\hline $\begin{array}{l}\text { 8. Have you been readmitted to the hospital in the } \\
\text { past } 4 \text { weeks? }\end{array}$ & $\square$ No & $\square$ Yes & \\
\hline If yes, for what reason? & & & \\
\hline $\begin{array}{l}\text { 9. Were you given any information about the management } \\
\text { of pain when you were discharged from the hospital } \\
\text { after your surgery? }\end{array}$ & $\square$ No & $\square$ Yes & \\
\hline If yes, was it adequate? & $\square$ No & $\square$ Yes & \\
\hline 10. Any other comments: & & & \\
\hline
\end{tabular}




\section{APPENDIX 2}

\section{The Medical Outcomes Trust 36-item health survey (SF-36) (Adapted with permission from references 13,14)}

\begin{tabular}{|c|c|}
\hline & SF-36 HEALTH SURVEY \\
\hline \multirow[t]{2}{*}{ Instructions: } & $\begin{array}{l}\text { This survey asks for your views about your health. This information } \\
\text { will help keep track of how you feel and how well you are able to do } \\
\text { your usual activities. }\end{array}$ \\
\hline & $\begin{array}{l}\text { Answer every question by marking the answer as indicated. If you } \\
\text { are unsure about how to answer a question, please give the best } \\
\text { answer you can. }\end{array}$ \\
\hline \multirow[t]{6}{*}{ 1. In general, $v$} & you say your health is: \\
\hline & Excellent \\
\hline & 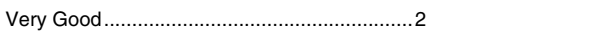 \\
\hline & Good \\
\hline & 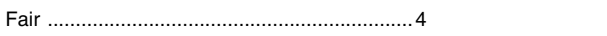 \\
\hline & Poor \\
\hline
\end{tabular}

2. Compared to one year ago, how would you rate your health in general now?

(Circle One)

Much better now than one year ago .............. 1
Somewhat better now than one year ago ........ 2
About the same as one year ago ................... 3
Somewhat worse now than one year ago $\ldots . . . .4$
Much worse than one year ago .................... 5

3. The following items are about activities you might do during a typical day. Does your health now limit you in these activities? If so, how much?

\begin{tabular}{|l|c|c|c|}
\hline \multicolumn{1}{|c|}{ Activities } & $\begin{array}{c}\text { Yes, } \\
\text { limited a lot }\end{array}$ & $\begin{array}{c}\text { Yes, limited } \\
\text { a little }\end{array}$ & $\begin{array}{c}\text { No, not } \\
\text { limited at all }\end{array}$ \\
\hline $\begin{array}{l}\text { a. Vigorous activities, such as } \\
\text { running, lifting heavy objects, } \\
\text { participating in strenuous sports. }\end{array}$ & 1 & 2 & 3 \\
\hline $\begin{array}{l}\text { b. Moderate activities, such as } \\
\text { moving a table, pushing a } \\
\text { vacuum cleaner, bowling, or } \\
\text { playing golf. }\end{array}$ & 1 & 2 & 3 \\
\hline c. Lifting or carrying groceries & 1 & 2 & 3 \\
\hline d. Climbing several flights of stairs & 1 & 2 & 3 \\
\hline e. Climbing one flight of stairs & 1 & 2 & 3 \\
\hline f. Bending, kneeling or stooping & 1 & 2 & 3 \\
\hline g. Walking more than a mile & 1 & 2 & 3 \\
\hline h. Walking several blocks & 1 & 2 & 3 \\
\hline i. Walking one block & 1 & 2 & 3 \\
\hline j. Bathing or dressing yourself & 1 & 2 & 3 \\
\hline
\end{tabular}

4. During the past 4 weeks, have you had any of the following problems with your work or other regular daily activities as a result of your physical health?

\begin{tabular}{|l|c|c|}
\hline \multicolumn{3}{|c|}{ (circle one number on each line) } \\
\hline \begin{tabular}{l} 
a. $\begin{array}{l}\text { Cut down on the amount of time you spent } \\
\text { on work or other activities }\end{array}$ \\
\hline b. Accomplished less than you would like
\end{tabular} & 1 & 2 \\
\hline $\begin{array}{l}\text { c. Were limited in the kind of work or other } \\
\text { activities }\end{array}$ & 1 & 2 \\
\hline $\begin{array}{l}\text { d. Had difficulty performing the work or other } \\
\text { activities (for example, it took extra effort) }\end{array}$ & 1 & 2 \\
\hline
\end{tabular}

5. During the past 4 weeks, have you had any of the following problems with your work or other regular daily activities as a result of any emotional problems (such as feeling depressed or anxious)?

\begin{tabular}{|l|c|c|}
\multicolumn{2}{l}{} & (circle one number on each line) \\
\hline $\begin{array}{l}\text { a. Cut down the amount of time you } \\
\text { spent on work or other activities }\end{array}$ & YES & NO \\
\hline b. Accomplished less than you would like & 1 & 2 \\
\hline $\begin{array}{l}\text { c. Didn't do work or other activities as } \\
\text { carefully as usual }\end{array}$ & 1 & 2 \\
\hline
\end{tabular}

6. During the past 4 weeks, to what extent has your physical health or emotional problems interfered with your normal social activities with family, friends, neighbors, or groups?

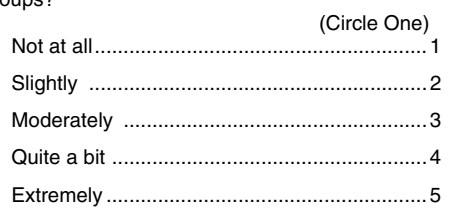

7. How much bodily pain have you had during the past 4 weeks?

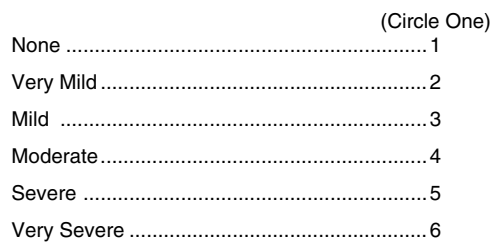

8. During the past 4 weeks, how much did pain interfere with your normal work (including both work outside and inside the home and housework)?

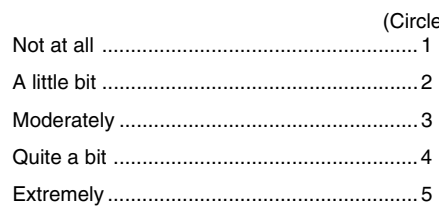

9. These questions are about how you feel and how things have been with you during the past 4 weeks. For each question, please give the one answer that comes closest to the way you have been feeling. How much of the time during the past 4 weeks:

(Circle one number on each line)

\begin{tabular}{|l|c|c|c|c|c|c|}
\hline & $\begin{array}{c}\text { All of } \\
\text { the time }\end{array}$ & $\begin{array}{c}\text { Most of } \\
\text { the time }\end{array}$ & $\begin{array}{c}\text { A Good } \\
\text { Bit of } \\
\text { the time }\end{array}$ & $\begin{array}{c}\text { Some } \\
\text { of the } \\
\text { time }\end{array}$ & $\begin{array}{c}\text { A little } \\
\text { of the } \\
\text { time }\end{array}$ & $\begin{array}{c}\text { None } \\
\text { of the } \\
\text { time }\end{array}$ \\
\hline $\begin{array}{l}\text { a. Did you feel full of } \\
\text { pep? }\end{array}$ & 1 & 2 & 3 & 4 & 5 & 6 \\
\hline $\begin{array}{l}\text { b. Have you been a } \\
\text { very nervous } \\
\text { person? }\end{array}$ & 1 & 2 & 3 & 4 & 5 & 6 \\
\hline $\begin{array}{l}\text { c. Have you felt so } \\
\text { down in the dumps } \\
\text { that nothing could } \\
\text { cheer you up? }\end{array}$ & 1 & 2 & 3 & 4 & 5 & 6 \\
\hline $\begin{array}{l}\text { d. Have you felt calm } \\
\text { and peaceful? }\end{array}$ & 1 & 2 & 3 & 4 & 5 & 6 \\
\hline $\begin{array}{l}\text { e. Did you have a lot } \\
\text { of energy? }\end{array}$ & 1 & 2 & 3 & 4 & 5 & 6 \\
\hline $\begin{array}{l}\text { f. Have you felt } \\
\text { downhearted and } \\
\text { blue? }\end{array}$ & 1 & 2 & 3 & 4 & 5 & 6 \\
\hline g. Did you feel worn out? & 1 & 2 & 3 & 4 & 5 & 6 \\
\hline h. Have you been a \\
happy person?
\end{tabular}

10. During the past 4 weeks, how much of the time has your physical health or emotional problems interfered with your social activities (like visiting with friends, relatives, etc.)?

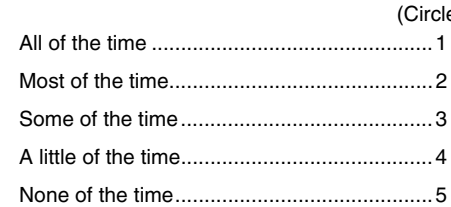

11. How TRUE or FALSE is each of the following statements for you?

(Circle one number on each line)

\begin{tabular}{|l|c|c|c|c|c|}
\hline & $\begin{array}{c}\text { Definitely } \\
\text { True }\end{array}$ & $\begin{array}{c}\text { Mostly } \\
\text { True }\end{array}$ & $\begin{array}{c}\text { Don't } \\
\text { Know }\end{array}$ & $\begin{array}{c}\text { Mostly } \\
\text { False }\end{array}$ & $\begin{array}{c}\text { Definitely } \\
\text { False }\end{array}$ \\
\hline $\begin{array}{l}\text { a. I seem to get sick a } \\
\text { little easier than other } \\
\text { people }\end{array}$ & 1 & 2 & 3 & 4 & 5 \\
\hline $\begin{array}{l}\text { b. I am as healthy as } \\
\text { anybody I know }\end{array}$ & 1 & 2 & 3 & 4 & 5 \\
\hline $\begin{array}{l}\text { c. I expect my health to } \\
\text { get worse }\end{array}$ & 1 & 2 & 3 & 4 & 5 \\
\hline d. My health is excellent & 1 & 2 & 3 & 4 & 5 \\
\hline
\end{tabular}

Copyright 1992 Medical Outcomes Trust. All rights reserved. (SF-36 Standard U.S. Version 1.0) 


\section{APPENDIX 3}

\section{Internet questions}

\section{Internet questions}

1. Do you have a computer in your home?

$$
\text { a Yes }
$$

․ No $\rightarrow$ go to question \# 3

2. How often did you use the computer in the past month?
- Not at all
a A few times
- About once a week
a Two to three times a week
- Almost daily
at least daily

3. Do you have internet access in your home?

$$
\begin{array}{ll}
\text { Y } \mathrm{Yes} \\
\text { № }
\end{array}
$$

4. How often did you use the internet in the past month?
- Not at all
- A few times
- About once a week
a Two to three times a week
a Almost daily
๑ At least daily

5. Would you be willing to complete these questions on a secure site on the internet?

$$
\text { ๑ Yes }
$$

№

6. Would you access information about pain management after surgery on an internet site?

$$
\text { ๑ Yes }
$$

$\begin{array}{ll}\text { ๑ } & \text { Nos } \\ \text { - No }\end{array}$

7. Would you complete a health history questionnaire on a secure internet site? a Yes

a No

\section{REFERENCES}

1. Macintyre PE, Ready LB. Acute Pain Management: A Practical Guide, 2nd edn. London: WB Saunders, 2001.

2. Morrison RS, Magaziner J, McLaughlin MA, et al. The impact of postoperative pain on outcomes following hip fracture. Pain 2003;103:303-11.

3. Macrae WA, Davies HT. Chronic postsurgical pain. In: Crombie IK, Croft PR, Linton SJ, SeResche L, Von Korff M, eds. Epidemiology of Pain. Seattle: IASP Press, 1999:125-42.

4. Chung F. Recovery pattern and home-readiness after ambulatory surgery. Anesth Analg 1995;80:896-902.

5. Wu CL, Naqibuddin M, Rowlingson AJ, Lietman SA, Jermyn RM, Fleisher LA. The effect of pain on health-related quality of life in the immediate postoperative period. Anesth Analg 2003;97:1078-85.

6. Macrae WA. Chronic pain after sternotomy. Acta Anaesthesiol Scand 2001;45:940-4.

7. Smith BH, Elliott AM, Chambers WA, Smith WC, Hannaford PC, Penny K. The impact of chronic pain in the community. Fam Pract 2001;18:292-9.

8. Elliott AM, Smith BH, Smith WC, Chambers WA. Changes in chronic pain severity over time: The chronic pain grade as a valid measure. Pain 2000;88:303-8.

9. McGrath B, Elgendy H, Chung F, Kamming D, Curti B, King S. Thirty percent of patients have moderate to severe pain $24 \mathrm{hr}$ after ambulatory surgery: A survey of 5703 patients. Can J Anaesth 2004;51:886-91.

10. Watt-Watson J, Chung F, Chan VW, McGillion M. Pain management following discharge after ambulatory same-day surgery. J Nurs Manag 2004;12:153-61.

11. Collins M, MacDonald V. Managing postoperative pain at home. Can Nurse 2000;96:26-9.

12. Goldstein DH, VanDenKerkhof EG, Rimmer MJ. A model for real time information at the patient's side using portable computers on an acute pain service. Can J Anaesth 2002;49:749-54.

13. Ware JE Jr. SF-36 Health Survey Manual and Interpretation Guide. Boston: The Health Institute, New England Medical Center, 1993.

14. Ware JE Jr, Kosinski M, Keller SD. SF-36 Physicial and Mental Health Summary Scales: A User's Manual. Boston: The Health Institute, New England Medical Center, 1994.

15. Hopman WM, Towheed T, Anastassiades T, et al. Canadian normative data for the SF-36 health survey. Canadian Multicentre Osteoporosis Study Research Group. CMAJ 2000;163:265-71. 